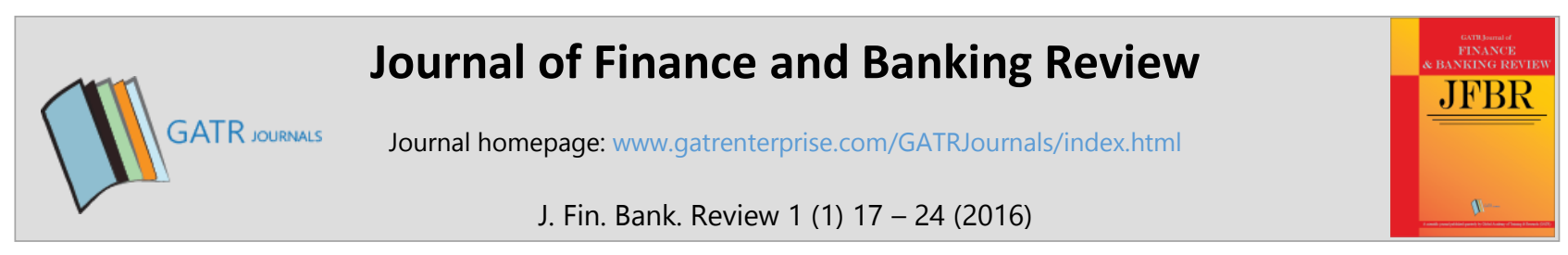

\title{
Analysis of Economic Performances and Factors Affecting Welfare in Central Java (2010 - 2013)
}

\author{
Dewi Ismoyowati ${ }^{1 *}$, Mugi Rahadjo ${ }^{2}$, Nurul Istiqomah ${ }^{3}$ and Leni Kurniawati ${ }^{4}$ \\ 1,2,3,4 Faculty of Economics and Business, Sebelas Maret University, Surakarta, Indonesia
}

\begin{abstract}
Objective - This study describes the economic performances of the Central Java province from 2010 to 2013 . In line with that, it analyses the effects of the economic performance, dependency ratio, employment, and fiscal decentralization on the welfare of the people in the region.

Methodology/Technique - This study uses the panel data of between 2010 and 2013. Data were analysed using descriptive analysis and multiple linear regression analysis.

Findings - Descriptive analysis of the Economic Performance Index indicates that the economic performance of regencies/cities in Central Java province has improved. Results of the Multiple Linear Regression analysis indicates that the economic performance, the young dependency ratio, and Regional Own-Source Revenue positively and significantly influences the welfare of the people in the region.

Novelty - It is recommended that local governments reduce the development inequality by directing the regional development towards its main characteristics. Local governments need coherence, consistency, and synchronization between development planning and funding as well as between the Local Government Unit where the accountability of the local government's performance is based on well-defined indicators and mechanisms.
\end{abstract}

Type of Paper: Empirical

Keywords: Economic Performance; Development gaps; HDI; Dependency Ratio; Employment; Fiscal Decentralization. JEL Classification: F63, H75.

\section{Introduction}

As an archipelago, Indonesia possesses unequal distribution of natural resources. One area could be rich in resources such as minerals while another could be poor. This imbalance is caused by the differences in endowment factors such as geographical locations and the characteristics of its human resources (Ehtisham et al., 2002: 212). The ability of the local governments to manage the development process is tested in their region where they are required to make appropriate policies that can promote development equality which can ultimately improve the welfare of the community, increase community participation in local development, improve and manage local financial potentials as well as optimize local economic performances.

\footnotetext{
* Paper Info: Received: October 14, 2016

Accepted: December 23, 2016

* Corresponding author:

E-mail: dewi_2986@yahoo.com

Affiliation: Faculty of Economics and Business, Sebelas Maret University, Indonesia
} 
The local governments do not just execute the instructions of the central government. They actually have the discretion and creativity to increase the development of potentials, something that was largely restricted during the centralization era (Mardiasmo, 2002: 57). This policy is a challenge and an opportunity for the local governments to manage their resources effectively and efficiently. This policy is beneficial for areas with reliable resources such as human and natural resources given that the nature of autonomy is an indication of the regional's authority rather than just a delegation (Saragih, 2003: 34).

In looking at a country's economic development, it cannot be denied that economic growth is the main target. This is because economic growth reflects a country's increase in production capacity. This indicator is used to measure the economic progress of national and regional development results and also as a basis for development planning. The rate of the economic growth in the Central Java province between 2009 and 2013 had increased, in line with the increase in GDP per capita. Table 1 indicates that the economic growth in Central Java had increased from 5.14 percent in 2009 to 5.81 percent in 2013. During this period the average economic growth rate was 5.83 percent per year.

Table 1. The RGDP, RGDP per capita and Growth Rate of Central Java Province for year 2009 - 2013 (Based on Constant Prices 2000)

\begin{tabular}{|l|c|c|c|c|c|c|}
\hline \multirow{2}{*}{ Details } & \multirow{2}{*}{$\begin{array}{c}\text { Unit } \\
\text { Rupiah }\end{array}$} & \multicolumn{5}{|c|}{ Year } \\
\cline { 3 - 7 } & $\mathbf{1})$ & $\mathbf{2 0 0 9}$ & $\mathbf{2 0 1 0}$ & $\mathbf{2 0 1 1}$ & $\mathbf{2 0 1 2}$ & $\mathbf{2 0 1 3} *$ \\
\hline RGDP & billion & $176,673.5$ & $186,993.0$ & $198,270.1$ & $210,848.4$ & $223,099.7$ \\
\hline $\begin{array}{l}\text { RGDP } \\
\text { without oil } \\
\text { and gas }\end{array}$ & billion & $166,176.2$ & $176,187.0$ & $187,244.9$ & $199,838.6$ & $212,304.9$ \\
\hline RGDP growth & percent & 5.14 & 5.84 & 6.03 & 6.34 & 5.81 \\
\hline $\begin{array}{l}\text { RGDP growth } \\
\text { without oil } \\
\text { and gas }\end{array}$ & percent & 5.66 & 6.02 & 6.28 & 6.73 & 6.24 \\
\hline $\begin{array}{l}\text { RGDP per } \\
\text { capita }\end{array}$ & thousand & 5462.2 & 5773.9 & 6112.9 & 6494.4 & 6909.3 \\
\hline $\begin{array}{l}\text { RGDP per } \\
\text { capita without } \\
\text { oil and gas }\end{array}$ & thousand & 5137.6 & 5440.2 & 5770.1 & 6155.3 & 6574.9 \\
\hline
\end{tabular}

Source: Central Bureau of Statistics, 2009-2013.

Remarks: * Preliminary figures

In most countries, the development goal of the government is to improve the welfare of its people which can be achieved by reducing the level of poverty. The percentage of poor people in any nation is one of the social indicators frequently used as an indicator to measure the success of regional economic development. Poverty, as defined by basic needs approach, is the economic inability to meet the basic needs of food and non-food as measured, based on expenditure (CBS, 2008; 29). Poor population is the population with their level of expenditure per capita per month below the poverty line.

Table 2. Number of Poor Population in Central Java Province for Year 2002 - 2013

\begin{tabular}{|c|c|}
\hline Year & Poor Population \\
\hline $\mathbf{( 1 )}$ & $\mathbf{( 2 )}$ \\
\hline 2002 & 7.308 .330 \\
\hline
\end{tabular}




\begin{tabular}{|l|l|}
\hline 2003 & 6.979 .800 \\
\hline 2004 & 6.843 .800 \\
\hline 2005 & 6.533 .500 \\
\hline 2006 & 7.100 .600 \\
\hline 2007 & 6.557 .200 \\
\hline 2008 & 6.122 .551 \\
\hline 2009 & 5.655 .412 \\
\hline 2010 & 5.215 .403 \\
\hline 2011 & 5.256 .000 \\
\hline 2012 & 4.952 .056 \\
\hline 2013 & 4.811 .343 \\
\hline
\end{tabular}

Source: Central Bureau of Statistics, 2002-2013.

The gap between districts/cities is also shown by a comparison of GDP per capita (current market prices for non-oil) between districts/cities in Central Java.

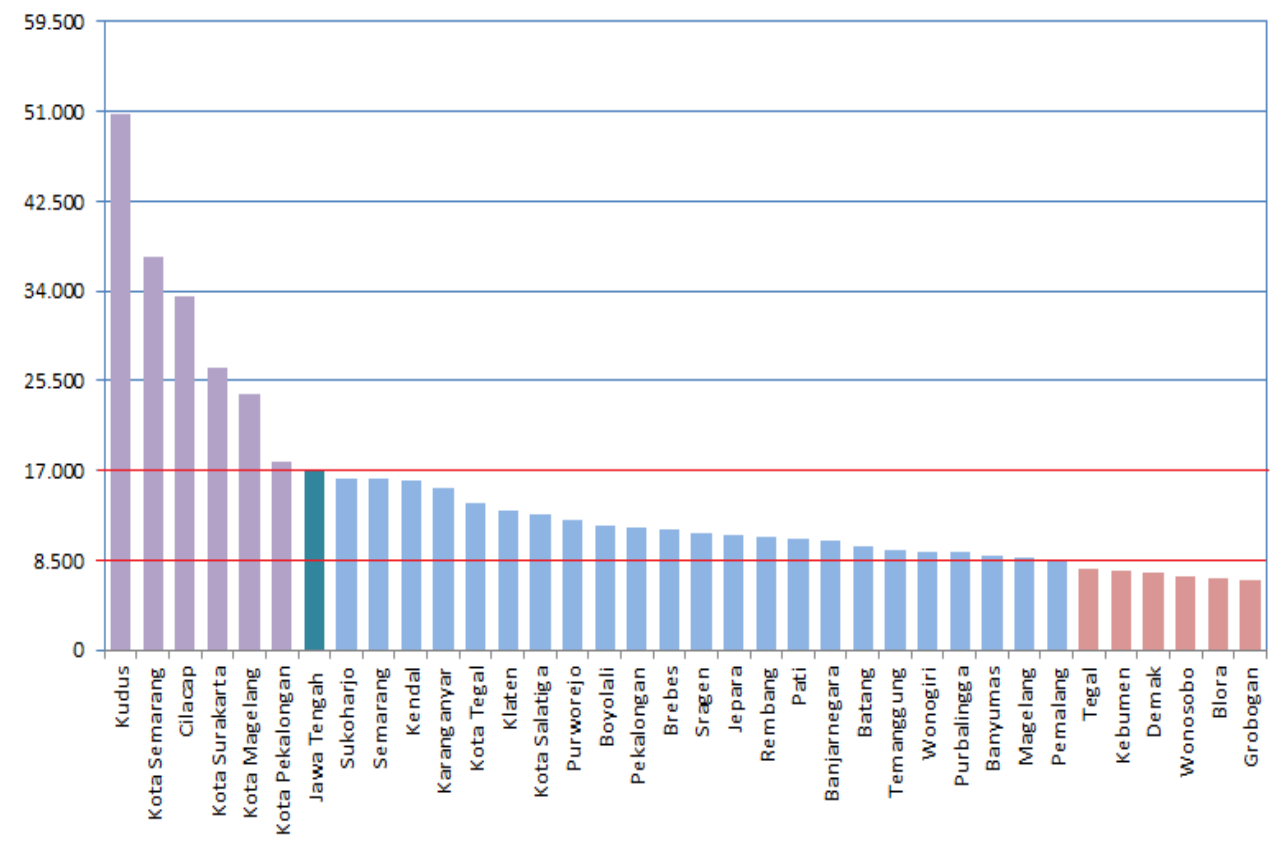

Figure 1. GRDP (current market prices for non-oil and gas) per capita by Regency/City in Central Java province in 2013 (Rp. 000)

Source: Central Bureau of Statistics, 2013. (Data processed)

Figure 1 illustrates that out of 35 (thirty five) regencies/cities noted in the Central Java province, only 6 (six) districts/cities have a higher GRDP per capita and they are Pekalongan City, Magelang City, Surakarta City, Cilacap District, Semarang District and Kudus District. In contrast, the other 29 districts/cities have a lower GDRP with six (6) of them having less than half of the GDRP per capita of Central Java.

The different levels of development performance noted between regions is due to the differences in potential resources owned by each region as such differences have an impact on the success of development across the country. A positive economic performance within a region can improve its people's welfare. In this regard, local governments need to optimize the economic performance of the respective regions by developing specific 
programs which are tailored to the needs and abilities of each region so that development quality can be improved.

The wide per capita income inequality noted among districts/cities in the Central Java province suggests that the regional economic performance has not been able to narrow the gap among the regions and so it was not able to improve the quality of the economic growth which could have improved the people's welfare. Bappenas (2008: 5) stated that there are two important issues related to improving the welfare of society: how the government implements it and how it impacts on society.

Referring to the recommendation of Bappenas (2008), it is thus deduced that the implementation of regional autonomy in districts/cities needs to be evaluated such that the evaluation 'output' will focus on the main aspects of public interest in maintaining their life, namely their economic conditions. Bappenas (2008: 5) had stated that if the economic conditions improve, it would indirectly improve people's access to public services such as education and health.

\section{Methods}

\subsection{Scope of Research}

This study was conducted in all the thirty five (35) regencies/cities of the Central Java province from 2010 to 2013. The study was developed based on the premises that:

1. Central Java Province is one of the provinces that is not experiencing regional administrative expansion after the implementation of regional autonomy policy. Bappenas and UNDP (2007) had stated that the evaluation of regional autonomy implementation shall not be performed to regions experiencing expansion area because they already show results that do not support the achievement of their people welfare.

2. The center of regencies/cities noted in the Central Java province lies in one expanse of the island of Java. It is expected that transportation and communication do not encounter significant barriers and the differences in resources and culture are not too great, so that all development processes run smoothly.

3. Central Java Province is not a special region.

4. Between 2010 and 2013, regional autonomy policy had been implemented for more than a decade. It is assumed that the policy has been running properly and the results of the regional development have been felt.

This study focused on the use of secondary data (Supranto, 2000) that were based on time series and cross sectional comparison. Firstly, the research data were taken from the period of 2010 to 2013 and secondly, they were extracted from all the regencies/cities in the Central Java province and obtained from literature published by authorities such as the Central Bureau of Statistics and the Directorate General of the Central and Local Fiscal Balance. Since data were fully obtained through literature review, sampling and questionnaires were unnecessary.

\subsection{Data analysis techniques}

There are two parts to the analysis. One focuses on Descriptive Analysis. The other focuses on Multiple Linear Regression analysis.

\section{a. Descriptive Analysis}

Descriptive analysis is used to analyze the processing results of the Economic Performance Index. These were used as indicators for the economic performance. Williamson's Index was used to assess the development inequality in all the regencies/cities in the Central Java province. 


\section{b. Multiple Linear Regression Analysis (MLRA)}

The MLRA was used to analyze the panel data of the regencies/cities in the Central Java province from 2010 to 2013. Panel data is a data that comprise of those extracted based on time series and cross sectional comparison.

Three approaches were used in processing the panel data analysis: common effect, fixed effect, and random effect.

\section{1) Common Effect}

The Common Effect approach combines time series and cross section data by combining the two types of data so that OLS can be used to estimate the panel data model. This approach does not pay attention to individual and time dimensions. It can be assumed that the data behavior between individuals is identical in a variety of timescales. These assumptions are far from actual reality because the characteristics between individuals in terms of territorial borders are evidently different.

2) Fixed Effect

The Fixed Effect model assumes that differences between the units of cross-sectional and time unit are shown in the various intercepts of the respective units. In the two-way fixed effects model, the intercept difference results from the two units: the cross-sectional unit and time unit. Thus, the difficulty of fulfilling consistent intercept and slope assumptions which can be done by inserting a dummy variable. The fixed effect modelling is generally performed by using the Least Square Dummy Variable (LSDV) which is the estimation method of the linear regression parameter which uses OLS on models involving dummy variables for one of the explanatory variables (Greene, 2007).

3) Random Effect

The addition of dummy variables will reduce the degree of freedom. This will subsequently reduce the efficiency of the estimated parameters. The Error component model or the Random effect model can then be used in the data panel model which involves the correlation between error terms as a result of the changing times caused by different observations. This model assumes that the influence of crosssectional unit and time unit is a random variable that can be included in the model as a form of error (Judge et al., 1980).

\subsection{Estimation Model}

This study looks at the effect of Economic Performance (EP), Dependency Ratio (DR), Workforce ( $\mathrm{W}_{\text {ind, }} \mathrm{W}_{\text {farmer), }}$ and Fiscal Decentralization (FDD1, FDD2, FDD3, FDD4) variables on Welfare (HDI) by using time series data of four years, from 2010 to 2013, and cross section data of 35 regencies/cities in the Central Java province coupled with 140 observations.

The model used is:

Or translated into:

$$
\mathrm{HDI}=f\left(\mathrm{EPI}, \mathrm{DR}_{\mathrm{young}}, \mathrm{DR}_{\text {old }}, \mathrm{W}_{\text {ind }}, \mathrm{W}_{\text {farmer }}, \mathrm{FDD}_{1}, \mathrm{FDD}_{2}, \mathrm{FDD}_{3}, \mathrm{FDD}_{4}\right)
$$

$$
\begin{gathered}
\mathrm{HDI}_{\text {it }}=\alpha_{0}+\beta_{1} \mathrm{EPI}_{1 \mathrm{it}}+\beta_{2} \mathrm{DR}_{\text {young }}+\beta_{3} \mathrm{DR}_{\text {old }}+\beta_{4} \mathrm{~W}_{\text {ind }}+\beta_{5} \mathrm{~W}_{\text {farmer }}+\beta_{6} \mathrm{FDD}_{1 \mathrm{it}}+\beta_{7} \mathrm{FDD}_{2 \mathrm{it}} \\
+\beta_{8} \mathrm{FDD}_{3 \mathrm{it}}+\beta_{9} \mathrm{FDD}_{4 \mathrm{it}}+\varepsilon_{\text {it }}
\end{gathered}
$$

Where: $\quad$ HDI $=$ Human Development Index

EPI $=$ Economic Performance Index

$\mathrm{DR}_{\text {young }}=$ Dependency Ratio Young

$\mathrm{DR}_{\text {old }}=$ Dependency Ratio Old

$\mathrm{W}_{\text {(ind) }}=$ Percentage of Workforce in Industrial Sector

$\mathrm{W}_{\text {(farmer) }}=$ Percentage of Workforce Agricultural Sector 


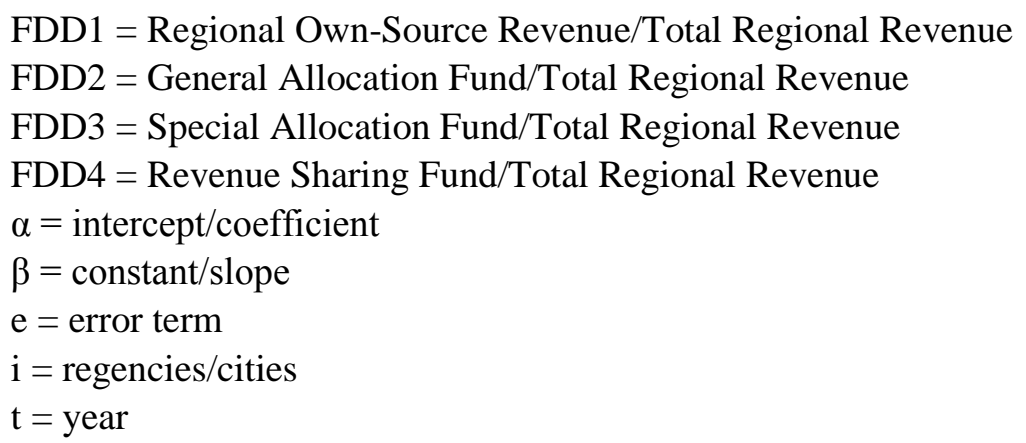

\section{Results and Discussions}

Results extracted from this study show that the economic performance of the region has improved. Regencies/cities in the Central Java province had sought to improve their economic performance by harnessing the potential of their respective regions. This condition is reflected in the rate of the economic growth that continues to increase, accompanied by an increase in per capita income and a reduction in poverty (Badan Pusat Statistik, 2014)

In general, the city administrative areas showed better performance than the regencies. This improvement was influenced by factors such as the greater number of inhabitants and stagnant contributions to the economy of the Central Java province. The contributions of the regencies/cities had remained unchanged but Semarang seems to be the city with the most stable economic performance, among all the regencies/cities in the Central Java province. This could be attributed to the existence of not one but many dominant sectors.

The enhanced economic performance has apparently, been unable to reduce development inequality between regencies/cities. As can be seen from Williamson's Index, the figure remained high throughout the study at approximately 0.69 as presented in Figure 2 .

Figure 2 also demonstrates that from 2010 to 2013, Williamson's Index value had decreased so slightly that it can be viewed as stagnant. In 2010, Williamson's Index of equality was 0.697 but in 2011, it had decreased to 0.695 and in 2013 it dropped to 0.692 . This slight decline indicates that the improved economic performance was not followed by a decrease in development inequality among regencies/cities in the Central Java province.

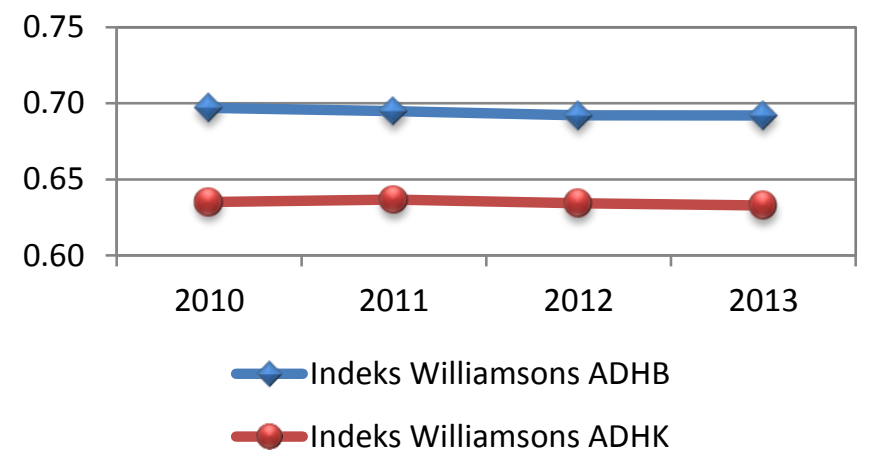

Figure 2. Williamson Index Development in Central Java Province 2010 - 2013

Source: Central Bureau of Statistics, 2014. (Data processed)

As can be seen from the figure, the city of Semarang has the most stable economic performance during the study. This stability can be seen in all constituent variables of the EPI such as economic growth rate, RGDP per capita, poverty level, and contribution to the economy of the Central Java province from year to year. The stability of Semarang is the result of the multi-sector economy, unlike other regencies/cities that generally focus on only one sector of the economy. 


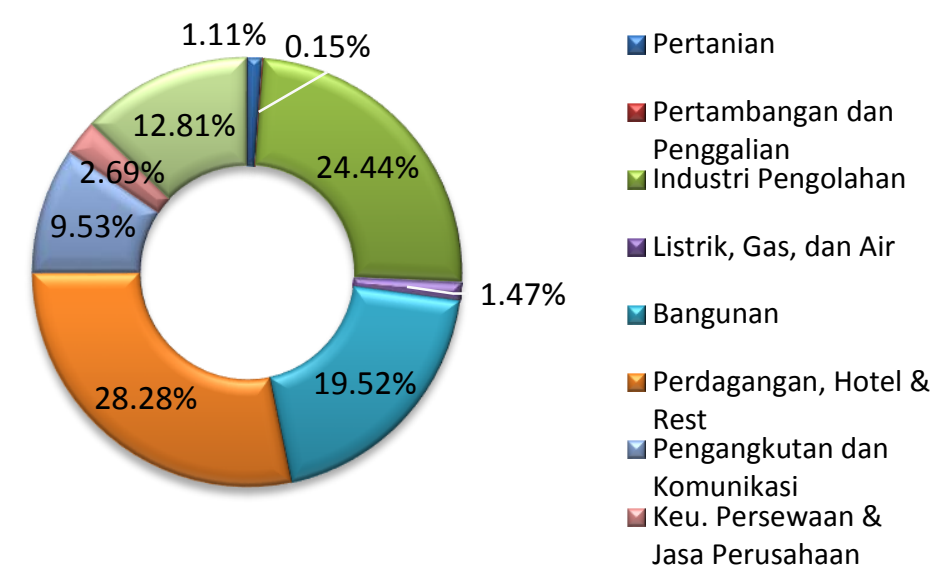

Figure 3. The average RGDP contributions of Semarang City based on Economic Sectors in Central Java Province 2010 - 2013

Source: Central Bureau of Statistics, 2014. (Data processed)

The analysis showing the correlation between regional economic performance, dependency ratio, employment, and fiscal decentralization and welfare in the Java Island using fixed effect model is shown as follows:

$$
\begin{aligned}
\mathrm{HDI}_{\mathrm{it}}=72.82155+0.278559 \mathrm{EPI}_{1 \mathrm{it}}+0.022743 \mathrm{DR}_{\text {young }}+0.007709 \mathrm{DR}_{\text {old }}+0.010664 \mathrm{~W}_{\text {ind }} \\
+ \\
+2.830820 \mathrm{~W}_{\text {farmer }}+2.422754 \mathrm{FDD}_{1 \mathrm{it}}+1.216373 \mathrm{FDD}_{2 \mathrm{it}}+13.63182 \mathrm{FDD}_{3 \mathrm{it}} \\
+4.399037 \mathrm{FDD}_{4 \mathrm{it}}+\varepsilon_{\mathrm{it}}
\end{aligned}
$$

From the statistics, it can be seen that the nine independent variables included in the equation were able to explain the variations noted in the HDI. Overall, the influence of the nine independent variables on welfare is 99.49 percent. The remaining 0.51 percent could have been influenced by other variables outside the model. Of the nine independent variables noted in the model, six showed a significant influence on welfare. In fact, the regional economic performance and its fiscal decentralization of the Regional Own-Source Revenue, shows a positive and significant correlation. The other four variables - workforce in agricultural sector, fiscal decentralization of General Allocation Funds, fiscal decentralization of Special Allocation Fund, and fiscal decentralization of Revenue Sharing Fund- showed a negative and significant relationship to welfare.

\section{Acknowledgements}

This study would like to thank the Head of the CBS, Surakarta and all the employees who assisted in the provision of the data and the preparation of this report. This study would also like to thank the rector of the UNS, LPPM UNS, P4M, and specifically, the Faculty of Economics and Business, UNS for providing the opportunity, suggestions and feedback to conduct this study. Finally, this study thank all the colleagues who have guided and provided valuable input to the study.

\section{References}

Badrudin, R. (2011). Pengaruh Belanja Modal dan Pertumbuhan Ekonomi terhadap Kesejahteraan Masyarakat Kabupaten/Kota di Provinsi Jawa Tengah. Jurnal Akutansi \& Manajemen, Vol. 22, No. 1, hal 39 -66.

Badrudin, R. (2012). Evaluasi terhadap Implementasi Otonomi Daerah : Tinjauan Empiris di Kabupaten/Kota Provinsi Jawa Tengah dan Daerah Istimewa Yogyakarta (Prosiding Kongres ISEI XVIII). PP-ISEI : Yogyakarta.

Bashir, A. \& Syamsurijal. (2012). Potret Perekonomian Daerah setelah Desentralisasi Fiskal di Provinsi Sumatera Selatan (Prosiding Kongres ISEI XVIII). PP-ISEI : Yogyakarta. 
Dao, M.Q.. (2012). Population and Economic Growth in Developing Countries. International Journal of Academic Research in Business and Social Sciences, 2(1)

Ehtisham, A., Jun M., Searle, B. \& Piperno, S. (2002). Intergovernmental Grant System : Application on General Framework to Indonesia. IMF Working Paper No.WP/02/128.IMF : Washington DC

Badan Perencanaan Pembangunan Nasional. 2013, Analisis Kesenjangan Antar Daerah 2013. BAPPENAS. Jakarta.

Central Bureau of Statistics,. 2008. Analisis dan Penghitungan Tingkat Kemiskinan 2008. Badan Pusat Statistik. Jakarta. 2013. Indeks Pembangunan Manusia 2013, Badan Pusat Statistik. Jakarta.

Central Bureau of Statistics. 2009. Jawa Tengah Dalam Angka 2009. Badan Pusat Statistik Provinsi Jawa Tengah. Semarang.

Central Bureau of Statistics. 2010. Jawa Tengah Dalam Angka 2010. Badan Pusat Statistik Provinsi Jawa Tengah. Semarang.

2011. Jawa Tengah Dalam Angka 2011. Badan Pusat Statistik Provinsi Jawa Tengah. Semarang.

2012. Jawa Tengah Dalam Angka 2012. Badan Pusat Statistik Provinsi Jawa Tengah. Semarang.

2013. Jawa Tengah Dalam Angka 2013. Badan Pusat Statistik Provinsi Jawa Tengah. Semarang.

2014. Jawa Tengah Dalam Angka 2014. Badan Pusat Statistik Provinsi Jawa Tengah. Semarang.

2009. Keadaan Angkatan Kerja di Jawa Tengah Tahun 2009. Badan Pusat Statistik Provinsi Jawa Tengah. Semarang.

2010, Keadaan Angkatan Kerja di Jawa Tengah Tahun 2010. Badan Pusat Statistik Provinsi Jawa Tengah. Semarang.

2011. Keadaan Angkatan Kerja di Jawa Tengah Tahun 2011. Badan Pusat Statistik Provinsi Jawa Tengah. Semarang.

2012. Keadaan Angkatan Kerja di Jawa Tengah Tahun 2012. Badan Pusat Statistik Provinsi Jawa Tengah. Semarang.

2013. Keadaan Angkatan Kerja di Jawa Tengah Tahun 2013. Badan Pusat Statistik Provinsi Jawa Tengah. Semarang.

2014. Keadaan Angkatan Kerja di Jawa Tengah Tahun 2014. Badan Pusat Statistik Provinsi Jawa Tengah. Semarang.

2014. Pemerataan Pendapatan dan Pola Konsumsi Penduduk Jawa Tengah Tahun 2012. Badan Pusat Statistik Provinsi Jawa Tengah. Semarang.

Gilarso, T. (2004). Pengatar Ilmu Ekonomi Makro. Kanisius : Yogyakarta.

J. Supranto. (2000). Teknik Sampling untuk Survei dan Eksperimen. PT. Rineka Cipta : Jakarta.

Mardiasmo.(2002). Otonomi dan Manajemen Keuangan Daerah.ANDI :Yogyakarta. 